\title{
TRANSFORMACJA INSTYTUCJONALNA TORU SLUŻEWIEC W WARSZAWIE A JEJ PAMIECTANIE W OBRĘBIE ZAMIESZKUJĄCEJ GO SPOŁECZNOŚCI SĄSIEDZKO-ZAWODOWEJ
}

\section{Streszczenie}

Artykuł zawiera studium instytucjonalnych przekształceń przedsiębiorstwa Państwowe Tory Wyścigów Konnych (PTWK) po 1989 r. oraz analizę pamięci komunikacyjnej tych przemian w obrębie społeczności byłego osiedla pracowniczego na terenie Toru Służewiec (obecna nazwa obiektu).

W pierwszej części tekstu zastał zrekonstruowany przebieg przekształceń oraz zwrotów na różnych szczeblach władzy, które miały miejsce w zakresie polityk wobec Toru Służewiec (TS) i instytucji wyścigów konnych w Polsce. Jego analiza ujawnia trwający od ponad ćwierć wieku proces dialektycznego inicjowania i wycofywanie się państwa z demonopolizacji i komercjalizacji tych obszarów. W rezultacie utrwalił się hybrydalny splot instytucji państwowych i prywatnych, które tworzą instytucję wyścigów konnych w Warszawie.

Instytucjonalna analiza przebiegu transformacji Toru stanowi kontekstowe wyjaśnienie dla drugiej części artykułu. W niej, w oparciu o badania własne o charakterze etnograficznym, omówione zostało pamiętanie tych przemian w ramach wspólnoty sąsiedzko-zawodowej TS. Dla mieszkańców niezbędna do opisania teraźniejszego życia i pracy jest opowieść o przeszłości. Zmiany zachodzące od ćwierć wieku na warszawskich wyścigach zlewają się w narrację upadku, który ma swoje materialne korelaty w pustostanach, ruinach i miejscach wyburzeń na terenie TS. Klamrę spinającą tekst stanowi teza, iż

\footnotetext{
* Dr, Instytut Socjologii; e-mail: bossakb@is.uw.edu.pl
} 
nietransparentny i odbierający sprawczość pracownikom PTWK przebieg transformacji instytucji wyścigów w Polsce, skutkuje uproszczeniem i idealizacją obrazów przeszłości, które pełnią funkcje objaśniające dla teraźniejszej kondycji Toru i społeczności jego mieszkańców

Słowa kluczowe: transformacja, pamięć społeczna, wyścigi konne, Tor Służewiec, PGR

\section{WSTĘP}

Teza o licznych, lecz niedostatecznie uwzględnianych związkach pamięci społecznej z gospodarką [Allen 2014] stanowiła inspirację do podjęcia rozważań o relacjach pomiędzy przebiegiem trwających od ćwierćwiecza przekształceń organizacji wyścigów konnych w Polsce a ich postrzeganiem w ramach społeczności mieszkańców Toru Służewiec (obecna nazwa obiektu, dalej TS lub Tor). Podczas realizacji badań terenowych wśród mieszkańców TS uderzyła mnie z jednej strony swoista amnezja dotycząca przekształceń instytucjonalnych z ostatniego ćwierćwiecza, z drugiej strony idealizacja przeszłości sprzed 1993 r. i pierwszych lat po likwidacji Państwowych Torów Wyścigów Konnych (dalej PTWK). Co więcej, pamięć komunikacyjna [Assmann 2008: 110] „wyścigowców" (kategoria emiczna) okazała się wyjątkowo jednorodna oraz zakotwiczona $\mathrm{w}$ topografii tego miejsca.

Zarówno organizacja Toru Służewiec, jak i instytucja wyścigów konnych w Polsce, spleciona z organizacją zakładów wzajemnych i hodowlą koni krwi angielskiej, tworzą struktury osobliwe [Gumuła 2008]. W latach 1950-1993 PTWK zajmowało się wszystkimi aspektami wyścigów konnych: ich organizacją, treningiem koni oraz organizacją zakładów wzajemnych. W okresie PRL-u wyróżniał je komponent wywodzący się z okresu kapitalizmu - tzw. koński totalizator, który stanowił wówczas jedyną legalną, obok loterii, grę hazardową.

Osobliwość wyścigów trwa też współcześnie. Tylko częściowa prywatyzacja instytucji wyścigów konnych w Polsce (własności i treningu koni), przy utrzymaniu państwowej własności warszawskiego Toru oraz organizacji wyścigów i totalizatora, powoduje, że wyścigi konne przypominają instytucję z okresu ? przejściowego transformacji ustrojowej 1989 r. [por. Gumuła 2008: 252-253]. Ponadto, pomimo burzliwych przekształceń organizacyjnych trwających od 1993 r., które wciąż wydają się nieukończone (ostatnie poprawki do ustawy 
o organizacji wyścigów konnych miały miejsce w 2016 roku) ${ }^{1}$, urbanistyczna struktura zabytkowego obiektu jest stała, co sprzyja trwaniu właściwej dla wielu PGR-ów kultury życia, która wynika z przenikania się przestrzeni zamieszkiwania i pracy [por. Szpak 2005].

Artykuł ma na celu analizę przebiegu procesów makrospołecznych i ich skutków na poziomie społeczności sąsiedzko-zawodowej na Torze Służewiec w Warszawie. Przed omówieniem fenomenu (nie)pamięci wśród „wyścigowców” rozpatruję warunki instytucjonalne, które kształtowały ich życie codzienne. Fakt, iż instytucje postrzegane są jako niespójne i dysfunkcyjne przez ,cichych bohaterów transformacji" [Rychard 2002], wydaje się jednym ze źródeł idealizacji okresu PRL-u. Aby jednak nie sprowadzić tego fenomenu do zjawiska nostalgii za komunizmem, zestawiam narracje pamięciowe „wyścigowców” z analizą transformacji ich miejsca pracy i zamieszkiwania na poziomie makrostrukturalnym, co umożliwia zrozumienie ograniczeń strukturalnych, w których znaleźli się byli pracownicy PTWK.

Po 1989 r. nie tylko politycy, ale także badacze społeczni licznie skupiali się na deklaratywnych, formułowanych w kategoriach modernizacyjnych, celach transformacji ustrojowej, zarówno gospodarczej, jak i politycznej [Wnuk-Lipiński 2001; Kowalik 2009: 144]. Podejmowano próby uogólnień teoretycznych dotyczących jej istoty, wyznaczając fazy i wskaźniki ich przechodzenia [Bałtowski, Miszewski 2007: 24]. Pod koniec lat 90. okazało się, że szczególnie tam, gdzie zlikwidowano duże przedsiębiorstwa państwowe, powstawały całe obszary „nowej biedy” [Tarkowska 2000: 54-61; Rakowski 2008: 5], na których nie nastąpiła „faza konsolidacji” kończąca modelowy proces transformacji społeczno-ekonomicznej [Wnuk-Lipiński 2001: 55]. Przyniosło to w kolejnych latach szereg analiz ujmowanych w kategoriach „kosztów transformacji” [Tarkowska 2013: 72], podziału na ,przegranych i wygranych” [Jarosz 2005], nowych badań dotyczących ubóstwa, bezrobocia oraz trwania „negatywnego zaufania społecznego" [Nowakowski 2008: 213]. Opisując u progu XXI wieku skutki transformacji, socjologowie sięgali po pojęcia podklasy [Karwacki 2006: 104], kultury biedy [Warzywoda-Kruszyńska 1998: 35] czy opóźnienia kulturowego [Sztompka 2000: 55-56]. Zwracano uwagę na powstawanie kultury systemowej bezradności [Giza-Poleszczuk, Marody, Rychard 2000: 85] czy kultury zależności [za: Tarkowska 2013: 49-80].

1 Ustawa z dnia 29 kwietnia 2016 r. O zmianie ustawy o wyścigach konnych, Dz. U. z 2016 r., poz. 967. 
$\mathrm{Na}$ niedostateczną konkluzywność licznych polskich badań stanu nowej biedy zwracała uwagę największa jej badaczka, Elżbieta Tarkowska [Tarkowska 2013: 54]. Przyczyną tego może być, między innymi, ograniczona liczba prac empirycznych (takich jak np. książka E. Dunn Prywatyzując Polskę: o bobofrutach, wielkim biznesie i restrukturyzacji pracy), które analizowałyby przebieg restrukturyzacji konkretnych zakładów pracy w okresie transformacji ustrojowej. Po drugie, część kategorii analitycznych stosowanych przez badaczy posiadało mniej lub bardziej wyraźny komponent normatywny. Emiczne postrzeganie przemian gospodarczych często nie było traktowane jako pełnowartościowe zjawisko kulturowe - głos mający równe prawo do bycia wysłuchanym, co głosy decydentów i ekspertów. Do wyróżniających się wyjątków należy praca T. Rakowskiego Lowcy, zbieracze. Praktycy niemocy: etnografia człowieka zdegradowanego.

„Od czasu Halbwachsa socjolodzy myślą o pamięci zbiorowej jako selektywnej rekonstrukcji przeszłości dokonywanej w odpowiedzi na potrzeby teraźniejszości" [Głowacka-Grajper 2006: 53]. Podazzając tym tropem, pokazuję, jak na Torze Służewiec mieszkańcy przekształcają swoje pamiętanie przeszłości, które stanowi część procesu generowania znaczeń i jako takie jest wytworem teraźniejszości [Misztal 2005: 108, 109; Golka 2009: 8-10]. Stawiam tezę, że dhugotrwały, niekonsekwentny i odbywający się przy znikomym udziale samych zainteresowanych przebieg transformacji instytucji wyścigów konnych skutkuje tworzeniem przez „wyścigowców” wyidealizowanych, ale też funkcjonalnych obrazów przeszłości [Szpociński 2006: 30], które pozwalają objaśniać bieżąca, złożoną instytucjonalnie, sytuację na Torze.

\section{O PROJEKCIE BADAWCZYM}

W 2013 r. został sporządzony projekt Miejscowego Planu Zagospodarowania Przestrzennego (dalej MPZP) przy ul. Kłobuckiej, który, między innymi, dopuszczał wprowadzenie nowych funkcji i zabudowy w niektórych częściach miasteczka wyścigowego. Jego treść wzbudzała szereg kontrowersji². W tym właśnie kontekście powstał projekt badawczy Tor Wyścigów Konnych Stużewiec $w$ Warszawie. Studium społecznych funkcji i znaczeń obszaru kulturowego w przededniu zmian, którego podstawowym celem było poznanie, jak Tor Służe-

2 Pisała o nich ówczesna prasa. Projekt MPZP przy ul. Kłobuckiej został zakwestionowany przez Stołecznego Konserwatora Zabytków oraz negatywnie zaopiniowany przez Narodowy Instytut Dziedzictwa i nie stanął na Radzie Miasta Stołecznego Warszawy. Obecnie opracowywana jest jego nowa wersja. 
wiec jest użytkowany oraz jakie są wobec niego postawy i oczekiwania różnych kategorii aktorów społecznych związanych z tym miejscem. W latach 2015-2016 przeprowadzono około stu wywiadów pogłębionych oraz setki pomniejszych rozmów z różnymi kategoriami aktorów społecznych związanych z Torem Służewiec. Większość miała charakter narracyjny i zogniskowany [Kvale 2012: 44, 127]. Przeprowadzono także szereg badań obserwacyjnych. Zgromadzone w ten sposób dane pozwoliły poszerzyć opis badanych światów społecznych o charakterystykę praktyk życia codziennego. Ponadto przeanalizowano artykuły prasowe z różnych okresów historycznych, opublikowane wspomnienia, wydania jubileuszowe oraz strony internetowe i fora dotyczące warszawskich wyścigów konnych. Zebrano także dane $\mathrm{z}$ zakresu historii Toru i związanych z nim ludzi dostępne $\mathrm{w}$ archiwach AAN, MRiRW, IPN oraz w Urzędzie Miasta Stołecznego Warszawy.

Prezentowany artykuł powstał na podstawie analizy zebranych w ramach wspomnianego projektu badawczego trzydziestu pięciu wywiadów pogłębionych z mieszkańcami Toru oraz z kilkoma innymi osobami związanymi zawodowo z Torem. W obrębie społeczności zamieszkującej Tor Służewiec dobór rozmówców miał na celu uwzględnienie wszystkich grup wiekowych oraz kategorii zawodowych dorosłych mieszkańców Toru Służewiec. Przebiegał dwutorowo: poprzez kontakty osobiste nawiązywane w stajniach i na hipodromie oraz metodą kuli śniegowej. Dla wielu pracowników stajennych już sama sytuacja rozmowy z osobą spoza środowiska wyścigowego była zdarzeniem niecodziennym. Natomiast trenerzy i dżokeje mieli skłonność do udzielania odpowiedzi, których oczekują od nich dziennikarze sportowi. Najmniej wywiadów zebrano z kobietami w wieku emerytalnym, które zazwyczaj nie pracowały w stajniach PTWK, a jako kasjerki, sprzątaczki czy kucharki. Większość z nich odsyłała badaczy do swoich mężów lub innych mężczyzn cieszących się uznaniem w środowisku $\mathrm{z}$ racji swoich osiągnięć jeździeckich bądź trenerskich.

Na potrzeby omawianego w artykule tematu zastosowana została metoda zwana rekonstrukcyjną analizą krzyżową (reconstructing cross-analysis) [Thompson 2000]. Relacje rozmówców nie były analizowane jako zamknięte całości o określonej dynamice narracji, ale stanowiły podstawę do poszukiwania wzorów opowiadania o przeszłości. Wątki, które pojawiały się najczęściej i były podobnie ujmowane przez większą liczbę rozmówców, stały się podstawą do ukazania społecznych reprezentacji okresu transformacji w badanej społeczności.

Opracowanie przekształceń PTWK do stanu obecnego zostało sporządzone na podstawie: zbioru PTWK w AAN, kilkudziesięciu artykułów prasowych („Gazeta Wyborcza”, „Polska The Times”, „Życie Warszawy”, „Passa”, „Puls Biznesu”, „Gazeta Polska”) oraz dokumentów zastanych: raportów NIK, dokumentacji 
Stołecznego oraz Mazowieckiego Konserwatora Zabytków, zapytań i interpelacji poselskich, zapisów z posiedzeń komisji sejmowych oraz własnych zapytań o informację publiczną. Należy podkreślić, że historia transformacji PTWK do stanu obecnego była wieloetapowa, złożona i trudna do zrekonstruowania z racji ograniczonej transparentności działań i komunikacji z otoczeniem społecznym różnego typu instytucji państwowych weń zaangażowanych. Nie tylko w wywiadach z mieszkańcami Toru, ale też przez lata w wielu artykułach prasowych formułowane były opinie i zarzuty/insynuacje dotyczące polityki wobec wyścigów konnych w Polsce, których nie da się jednoznacznie zweryfikować.

Prezentowany artykuł powstał dzięki realizacji projektu badawczego Tor Wyścigów Konnych Stużewiec w Warszawie. Studium społecznych funkcji i znaczeń obszaru kulturowego w przededniu zmian nr 2014/13/B/HS6/04048, który został sfinansowany ze środków Narodowego Centrum Nauki³

\section{TOR SŁUŻEWIEC - PRZYBLIŻENIE}

Teren TS leży między dwiema tętniącymi życiem dzielnicami Warszawy, około siedmiu kilometrów od ścisłego centrum. Obecnie obejmuje około 138 ha (więcej niż jakikolwiek park stołeczny) o luźnej zabudowie. Szeroka aleja dojazdowa i skarpa dzielą go na hipodrom i miasteczko wyścigowe. Za około sześciokilometrowym murem pokrytym graffiti znajduje się zamknięte osiedle, na którym zameldowanych jest ośmiuset trzydziestu sześciu mieszkańców (stan na 6 sierpnia 2016), a w sąsiadujących z budynkami mieszkalnymi stajniach mieszka podobna liczba koni. Poza torem treningowym i terenami przystajennymi dziesiątki hektarów terenów wewnętrznych stanowią dziś nieużytki noszące ślady dawnych założeń parkowych i gospodarczych.

Zbudowany w duchu międzywojennego modernizmu TS był największą inwestycją prywatną w międzywojennej Warszawie. Inwestorem i właścicielem obiektu było Towarzystwo Zachęty do Hodowli Koni. Po II wojnie światowej, w 1950 r., na bazie znacjonalizowanego majątku powstało na Torze przedsiębiorstwo PTWK. Prywatna własność została przekształcona w PGR, a mieszkania na

\footnotetext{
3 Dotychczasowe publikacje zawierają: (1) omówienie obecnego charakteru organizacji i dostępności przestrzennej Toru Służewiec [Bossak-Herbst 2015]; (2) popularnonaukowy zarys historii budowy oraz opis terenu Toru Służewiec [Bossak-Herbst 2016]. Kierownikiem projektu jest Barbara Bossak-Herbst; prace badawcze realizowali także Małgorzata Głowacka-Grajper, Wojciech Ogrodnik, Karolina Dołęga, Maja Durlik i Rafał Rudnicki. Obecnie w ramach projektu realizowany jest film etnograficzny o życiu codziennym na Torze Służewiec.
} 
wynajem dla prywatnej służby stajennej w osiedle pracownicze. Dopływ koni do treningu gwarantowały także znacjonalizowane w całym kraju stadniny.

W okresie PRL-u w miasteczku wyścigowym działało także duże gospodarstwo rolne. Do 1993 r. nowi pracownicy dopływali tu z terenów wiejskich. Mężczyźni zatrudniani byli zazwyczaj w wieku szesnastu lat i rozpoczynali pracę jako „chłopcy stajenni”. Do czasu założenia rodziny zamieszkiwali w hotelu pracowniczym i dokształcali się w szkole na terenie zakładu. Ich żony, pochodzące najczęściej z rodzinnych stron, a w kolejnych pokoleniach z osiedla pracowniczego TS, pracowały sezonowo w kasach na Torze, jako sprzątaczki (m.in. w hotelu zakładowym), kucharki czy opiekunki w zakładowym przedszkolu. W okresie PRL-u starsi pracownicy byli dwukrotnie przenoszeni do dobudowywanych na terenie przedsiębiorstwa nowych bloczków, tym samym zwalniając przystajenne domy nowym pracownikom.

Obecnie w około połowie gospodarstw domowych „ludzi z Wyścig” (kategoria emiczna) przynajmniej jedna osoba nadal jest związana z pracą w stajniach i treningiem koni wyścigowych. Wiele stajni, które są dziś prywatnymi firmami prowadzonymi przez trenerów, boryka się z problemami finansowymi. Niskie zarobki powodują ciagły deficyt i rotację pracowników - zarówno wśród obsługi stajennej, jak i jeźdźców. W Polsce Tor Służewiec jest niemal tożsamy z instytucją wyścigów konnych, ponieważ jest jedynym hipodromem czynnym przez kilkadziesiąt dni w roku. Z tego też względu, inaczej niż w większości państw Europy Zachodniej czy USA, trenerzy, jeźdźcy i stajenni rzadko wyjeżdżali i wyjeżdżają poza jego mury w celach zawodowych. Wiejskie pochodzenie zdecydowanej większości mieszkańców, izolacja przestrzenna oraz nietypowy dla miasta rytm i charakter pracy powodują, że pomimo likwidacji PGR-u wciąż tworzą oni zamknięte środowisko. W jego ramach pamięć o powojennej historii wyścigów konnych w Polsce ma charakter biograficzny i komunikacyjny [Assmann 2008], jej treści są zaś nieobecne w tekstach kulturowych o wyścigach konnych w Polsce.

\section{Instytucjonalny przebieg transformacji Państwowych Torów Wyścigów Konnych}

Termin „zmiana systemowa” sugeruje ukierunkowanie i spójność przemian w Polsce po 1989 r. Dokonywana przez różne ośrodki władzy transformacja PTWK w szereg nowych podmiotów wydaje się jednak zaliczać je do ,procesów osobliwych”, które „w znacznym stopniu pozostają poza zakresem stosowalności klasycznych teorii socjologicznych, które ze swej natury koncentrują się na typowych aspektach trwania społeczeństwa" [Gumuła 2008: 8]. Kategorie funkcji 
jawnych i ukrytych [Merton 2002: 131-150], jako kategorie uwrażliwiające, pozwalająjednak uwypuklić powtarzający się wzór w rozbieżnościach pomiędzy motywacjami jawnymi decydentów transformacji w obszarze wyścigów konnych, których istotą było urynkowienie i zarazem utrzymanie instytucji wyścigów konnych, a obiektywnymi konsekwencjami lub domniemaniem ich zaistnienia, czyli funkcjami ukrytymi określonych zmian instytucjonalnych, które mogłyby doprowadzić do ich likwidacji.

Przez środowiska wywodzące się z PTWK, jak i część dziennikarzy za kluczowe dla zachowania instytucji wyścigów konnych w Polsce uznane zostało zachowanie ich centralnej lokalizacji na Torze Służewiec. Faktycznie, rozległy teren z niezbędną infrastrukturą mieszkalno-treningową zapewnił jej trwanie nawet $w$ wieloletnim okresie instytucjonalnego rozkładu w latach 1993-2008 i równocześnie stanowił mniej lub bardziej jawny przedmiot rywalizacji różnych podmiotów deklarujących zainteresowanie organizacją gonitw i zakładów wzajemnych. Jeszcze w 1974 r. część terenów PTWK, które znajdowały się poza murem, zaanektowano pod budowę Ursynowa Północnego. W 1989 r. naczelny architekt Warszawy ponownie, wbrew protestom PTWK, powiększył granice inwestycji Spółdzielni Ursynów oraz przekazał spółdzielniom pracowniczym kolejne działki ${ }^{4}$. Zainteresowanie terenami PTWK, także wewnątrz jego murów, zgłaszały różne spółdzielnie znajdujące się na Służewcu. W celu ochrony terenu w 1989 r. dyrektor PTWK założył przedsiębiorstwu księgę hipoteczną oraz doprowadził do jego wpisania (oraz części obiektów na Torze) do rejestru zabytków m. st. Warszawy. Kilka miesięcy później grupa inicjatywna, mająca na celu reaktywowanie Towarzystwa Zachęty do Hodowli Koni w Polsce, zaczęła dążyć do rewindykacji całego terenu przedsiębiorstwa.

19 października $1991 \mathrm{r}$. Sejm uchwalił ustawę o gospodarowaniu nieruchomościami rolnymi Skarbu Państwa ${ }^{5}$. Założony cel- „dostosowanie do warunków gospodarki wolnorynkowej" - miał być realizowany poprzez przechodzenie majątków PGR-ów do Zasobu Własności Rolnej Skarbu Państwa i ich odsprzedaż podmiotom prywatnym. W okresie przejściowym zakładano, że najbardziej odpowiednią formą zarządzania będą różne formy ich dzierżawy od Agencji Rolnej Skarbu Państwa [Dzun 2005: 171-192]. Jednak do końca 1993 r. PTWK oraz stadniny państwowe działały na podobnych zasadach jak w PRL-u. Od 1989 r. trwał konflikt o to, który podmiot ma obowiązek utrzymywać państwowe konie

\footnotetext{
4 Obecnie znajduje się na tym terenie osiedle Spółdzielni „Techniczna”.

5 Ustawa z dnia października 1991 r. O gospodarowaniu nieruchomościami rolnymi Skarbu Państwa, Dz. U. z 1991 r., poz. 464.
} 
w okresie treningu na Służewcu - PTWK czy stadniny, które przeszły na własność Agencji Własności Rolnej Skarbu Państwa (zwanej dalej Agencją). Agencja nie uiszczała opłat za utrzymanie i trening koni i dążyła do przejęcia majątku Toru. Dyrekcja PTWK starała się temu przeciwdziałać i nie postawiła przedsiębiorstwa w stan likwidacji aż do finalnego etapu likwidacji PGR-ów w grudniu 1993 r. Odbyło się to bez konsultacji z władzami przedsiębiorstwa, radą pracowniczą czy związkami zawodowymi na terenie PTWK. W miejsce przedsiębiorstwa Agencja powołała spółkę z ograniczoną odpowiedzialnością Służewiec - Tory Wyścigów Konnych (S-TWK). Zgodnie z obowiązującym prawem był to niezbędny krok ku jego dalszej prywatyzacji na drodze publicznej oferty sprzedaży [Surdykowska 1996: 143]. Od tego momentu także prawo do organizowania gier losowych miały tylko spółki akcyjne z ograniczoną odpowiedzialnością.

Po likwidacji PTWK trening koni został sprywatyzowany. Dotąd trenerzy byli zatrudnieni przez przedsiębiorstwo i otrzymywali odpowiednią liczbę koni do treningu ze stadnin państwowych. W 1993 r. zostali postawieni przed wyborem: otworzenia własnej działalności gospodarczej, wynajmowania budynków stajni od spółki oraz szukania na własną rękę prywatnych właścicieli gotowych wstawić do nich konie do treningu albo rezygnacji z zawodu. Zainteresowanie dzierżawą i kupnem koni wyścigowych w kraju nie było duże. W kolejnych latach, aby utrzymać się w zawodzie, większość trenerów samodzielnie zaczęła dzierżawić i kupować konie, wielu nie opłacało czynszu. Wraz z przedsiębiorstwem likwidacji uległa też jego część socjalna: usługowa i gospodarcza. Część została sprywatyzowana i funkcjonowała jeszcze przez kilka lat (stołówka, pralnia, przychodnia, hotel, szpital dla koni). Pozostałe instytucje - szkoła dla dorosłych, kluby sportowe i kulturalne, zostały zlikwidowane. Pozostałe po nich budynki, o ile nie uzyskały w 1989 r. statusu zabytku, w większości zburzono (jednak dopiero w $2016 \mathrm{r}$.).

W 1995 r. Ministerstwo Finansów zakwestionowało prawo spółki S-TWK do prowadzenia zakładów wzajemnych. Postawiono wymóg, aby tworzyły ją trzy podmioty. Od tego momentu wśród byłych pracowników urzędowych PTWK zatrudnionych teraz w spółce narastała obawa, że ruchy te służą podzieleniu i komercjalizacji terenu. Ówczesny prezes spółki, wcześniej pracownik PTWK, wspomina:

Była wielka obawa, chodziło o to, żeby nie wypuścić z rąk terenu. Od początku zęby sobie ostrzyli przeróżni deweloperzy... [...]. Miałem mnóstwo pracowników i długi. Byłem przekonany, że to może funkcjonować. Jednak z góry wiedziałem, że bez totalizatora nie da się tego spiąć. Sceptycznie patrzyłem na te przekształcenia i optymizm, że to niewidzialna ręka rynku ureguluje [mężczyzna, lat ok. 70, prezes spółki S-TWK]. 
Powyższy cytat ilustruje powszechne obawy w środowisku wyścigowym przed zmianami, których obiektywne dalekosiężne konsekwencje byłyby różne od oficjalnie założonych celów (prywatyzacja i wzmocnienie wyścigów konnych w Polsce). Jak wykazał Merton, różnice między legalnym a nielegalnym biznesem maja charakter moralny, jednak w sferze funkcjonalnej zachowują wiele homologii [Merton 2002: 148-149]. Przez kolejne lata na Torze obawiano się stworzenia instytucjonalnych warunków do przejęcia TS przez podmioty, które dla zysku mogłyby zmienić jego funkcje. Żaden z nich nie zajmował się wcześniej wyścigami konnymi, w związku z czym nie budził zaufania w środowisku.

W połowie lat 90 . liczba biznesmenów i osób publicznych inwestujących w konie była największa. Część posiadała pomysły na reorganizację wyścigów. Inwestorzy reprezentowali różne branże. O nasileniu wpływów mafijnych na Torze Służewiec w latach 90. szeroko rozpisywała się prasa. Regularnie sugerowano, że ustawiane gonitwy służą pomnażaniu i praniu brudnych pieniędzy. W 1995 r. nowym prezesem spółki została osoba związana ze środowiskiem wyścigowym, która, wedle jej słów, przez kolejne lata, „z pomocą wielu ludzi dobrej woli", powstrzymała cztery próby prywatyzacji tego terenu. W zeznaniach przed Komisją Hazardową wskazywała konkretne prominentne osoby zainteresowane dokonaniem prywatyzacji. W okresie „dzikiego kapitalizmu” lat 90. [Upchurch, Marinkovic 2011: 316-333; Harper 2006: 3-4] szara strefa bywała wyrazem głębszych, niekiedy dopiero rodzących się struktur społecznych, niewidzialnych na „powierzchni” oficjalnego systemu gospodarczego. Jej widoczne elementy często stanowiły zaczyn oficjalnego sektora gospodarki w kolejnych latach [Mosiej 2016: 140-167]. Parafrazując Mertona, w celu wyrażenia postaw dominujących wówczas w środowisku wyścigowym - zarówno wśród decydentów, jak i mieszkańców Toru - regularnie zaczęto domniemywać istnienia niejawnych motywacji u tych, „co przychodzili z zewnątrz”, których efektem miałyby być ujawniające się w długiej perspektywie właściwe cele (likwidacja wyścigów i zmiana funkcji TS).

Przez lata bezskutecznie szukano dla spółki S-TWK wiarygodnych inwestorów, których obecność była warunkiem posiadania pozwolenia na organizacje zakładów. U progu 2000 r. Ministerstwo Finansów utrzymało interpretacje zakazującą spółce organizowania zakładów wzajemnych (z których od $1993 \mathrm{r}$. Tor Służewiec jednak wciąż się utrzymywał). W tych okolicznościach właściciel, czyli Agencja, oddał ją za symboliczną złotówkę innej spółce Skarbu Państwa - Totalizatorowi Sportowemu (dalej TS z o.o. lub Totalizator). TS z o.o. zostało zobowiązane na mocy umowy do spłaty wierzycieli spółki, inwestowania w Tor i organizacji wyścigów przez kolejne 30 lat. W następnych miesiącach, 
w wyniku kolejnych zmian ustawowych, również Totalizator Sportowy utracił prawo organizowania zakładów wzajemnych. W tych okolicznościach zwrócił spółkę do ministra skarbu państwa. W rezultacie tej decyzji spółka pogrążała się w długach. Kolejny sezon z rzędu sporadycznie wypłacano właścicielom koni nagrody, a oni z kolei nieregularnie rozliczali się z pracującymi dla nich trenerami. Przekładało się to na długotrwałe zaniechania trenerów w opłacaniu czynszu za wynajem stajni i opłacaniu pracowników stajennych, czego skutki odczuwalne są do dziś. 17 stycznia 2001 r. nowy prezes Totalizatora oddał spółkę S-TWK Skarbowi Państwa, zaś prezes spółki złożył wniosek o jej upadłość.

Kilkanaście godzin później, 18 stycznia 2001 r., doszło w Sejmie do uchwalenia ustawy o wyścigach konnych, nad której treścią od lat pracowało wielu ludzi na różne sposoby związanych z wyścigami. Na jej mocy powołano osobę prawną Skarbu Państwa o nazwie Polski Klub Wyścigów Konnych (dalej PKWK). Jego prezesa zatwierdzał (a od $2016 \mathrm{r}$. powołuje) minister rolnictwa. PKWK otrzymał zadanie organizacji instytucjonalnej wyścigów, ale bez możliwości ich prowadzenia. Najważniejszy dla „wyścigowców” był jednak 12 paragraf ustawy, w którym przekazywano PKWK niezbywalne prawo własności terenu Toru Służewiec i znajdującego się na nim majątku. Możliwość fragmentaryzacji, dzierżawy na inne cele i sprzedaży terenu zostały prawnie zablokowane. Od wejścia w życie ustawy spółka S-TWK dzierżawiła obiekt od PKWK.

Po 1991 r. przekształcanie PGR-ów w jednoosobowe spółki Skarbu Państwa właściwie nie było realizowane [Dzun 2005: 171-192]. W tym jednak przypadku, po ośmiu latach próby urynkowienia wyścigów, zdecydowano się na taki zabieg. Jedna z osób zaangażowanych w tworzenie ustawy skwitowała to następująco:

Dzięki temu tor jest do dziś, bo już miał być pod gruz [mężczyzna, lat ok. 75, pracownik PKWK].

Prezes spółki S-TWK złożył wniosek o wycofanie wniosku o ogłoszenie upadłości spółki. Po kilku miesiącach zawieszenia kolejne zmiany przepisów ustawy hazardowej spowodowały, że od sezonu 2003 spółka mogła znowu prowadzić zakłady wzajemne. Nowy prezes (spoza środowiska wyścigowego) proponował przekształcenie głównego toru w ośrodek sportowo-wypoczynkowy, który miał służył organizacji mistrzostw Europy, ale także i mistrzostw świata w piłce nożnej, a może i olimpiady. Budziło to żywą niechęć mieszkańców i pracowników Toru. Z końcem 2003 r. przestał obowiązywać miejscowy plan ogólnego zagospodarowania przestrzennego m.st. Warszawy.

Spółka S-TWK nie wywiązywała się nadal z zobowiązań wobec właścicieli, trenerów i dżokejów. Wprowadziła firmę zagraniczną do obsługi komputerowego 
systemu zakładów, u której się zadłużyła. U progu 2004 r. PKWK, czyli ustawowy właściciel Toru, wypowiedział jej dzierżawę. Sąd zaproponował opcję układową i przekazał zarząd majątkiem zarządcy sądowemu. Skarb Państwa obniżył kapitał spółki po to, aby jej udziały mógł objąć ewentualny nowy inwestor. Po odrzuceniu kilku ofert firm zagranicznych przez Ministerstwo Finansów prezes spółki złożył do sądu gospodarczego wniosek o ogłoszenie upadłości obejmującej likwidację majątku.

Ministerstwo Skarbu Państwa stało w tym okresie na stanowisku, iż Totalizator powinien ponownie nieodpłatnie przejąć od PKWK funkcję powiernika mienia Skarbu Państwa. Stanowisko MRiRW było odmienne. Uważano, że skoro Totalizator, jako spółka Skarbu Państwa, podlega rygorom prawa handlowego i upadłościowego, to hipotetyczna upadłość TS z o.o. skutkowałaby wyprzedażą nieruchomości przez syndyka masy upadłościowej, czyli w tym wypadku byłaby równoznaczna z wyprzedażą terenu TS. W tym scenariuszu ustawa stanowiła wciąż niewystarczające zabezpieczenie jego integralności. Pokazuje to, że zarówno szeroko rozumiane środowisko wyścigowe, jak i część decydentów obawiała się konsekwencji urynkowienia własności tego majątku.

Podsumowując pierwszą dekadę po likwidacji PTWK, można zauważyć, że decydenci zajmujący się sprawami Toru starali się uniknąc trzech scenariuszy. Po pierwsze, przejścia spółki pod kontrolę prywatnych inwestorów na skutek sprzedaży znacznej części jej udziałów. Po drugie, prywatyzacji spółki i utraty kontroli nad majątkiem TS przez środowisko wyścigowe. Po trzecie, likwidacji spółki.

Zgodnie z planem MSP latem 2006 r. po raz drugi została podpisana umowa dzierżawy na 30 lat pomiędzy TS z o.o. i PKWK. Kilka tygodni później ekspertyzy budowlane dotyczące stanu trybun okazały się krytyczne - wskazywano w nich, że niosą one zagrożenie katastrofą budowlaną. Totalizator po raz drugi wycofał się z umowy. Latem 2006 r. nowy wicepremier i minister rolnictwa wyasygnował kwotę, dzięki której ruszył sezon 2006 (w sierpniu, a nie w kwietniu). Pieniądze trafiły do państwowej stadniny w Łącku, która została organizatorem wyścigów na kolejne dwa lata. Osobliwość instytucjonalną wyścigów konnych dobrze oddaje anegdota ówczesnego prezesa spółki S-TWK:

Kiedyś Wojnarowski [prezes stadniny Łąck] mówi: „Słuchaj, musimy napisać do ministra, by wyjaśnić coś tam ..." no i napisałem co jest nieprawidłowo. No i po trzech tygodniach dostaję na moim biurku prośbę, żebym odpowiedział Wojnarowskiemu. Bo było tak: napisałem do ministra, minister do prezesa Agencji, prezes Agencji do oddziału, no i dyrektor do mnie [śmiech] [mężczyzna, lat ok. 70, prezes spółki S-TWK]. 
W tym okresie PTWK poszukiwał dalej organizatorów-inwestorów, m.in. poprzez ogłoszenia na łamach prasy. Wobec braku wiarygodnych ofert Ministerstwo Rolnictwa oraz Ministerstwo Finansów ponownie zainicjowały proces przekazania organizacji wyścigów konnych TS z o.o. (po raz trzeci). W tym czasie syndyk wyprzedawał te elementy dobytku TS, które nie miały zabytkowego statusu.

Stan upadłości, podczas którego syndyk sądowy organizował wyścigi, trwał dwa lata. Przez cały okres transformacji mieszkańcy Toru dowiadywali się o kolejnych przekształceniach albo z prasy, albo z plotek rozchodzących się z biur ulokowanych przy trybunach, kolejno PTWK, spółki S-TWK, TS z o.o. i PKWK. Otwieranie się przed Polakami kolejnych rynków pracy w Europie Zachodniej powodowało, że po 2006 r. wyjazdy pracowników stajennych przestały mieć charakter jednostkowy. Na wyścigach brakowało rąk do pracy. Teren Toru okresami stał wówczas otwarty, co powodowało, że zaczął być użytkowany jako miejsce poszukiwania złomu, a przede wszystkim, jako miejsce libacji i noclegu. Ubywało zleceniodawców dla trenerów, ponieważ przez lata nagrody dla właścicieli były wypłacane nieregularnie i nie zawsze w całości. W tym okresie doszło też do radykalnej redukcji publiczności wyścigowej: na cotygodniowych gonitwach pozostali głównie zagorzali gracze, spadły znacząco pule zakładów.

14 maja 2008 r. Totalizator Sportowy po raz trzeci został organizatorem wyścigów. W ramach nowej umowy zobowiązał się do realizacji zadań w trzech obszarach: realizacji inwestycji, rozwoju wyścigów konnych i rozwoju zakładów wzajemnych. Treść umowy między PTWK i TS była utajniona. Nieznany jest mechanizm finansowania wyścigów przez TS z o.o. W 2012 r. jeden z członków Rady PTWK informował na łamach prasy o istnieniu lokaty celowej utworzonej przez ministra skarbu, z której TS utrzymuje organizację wyścigów. Do tych rewelacji, przeczących wypowiedziom publicznym decydentów TS o konieczności dofinansowywania przez Totalizator deficytowych wyścigów, nigdy nie odnieśli się publicznie jego reprezentanci czy przedstawiciele Ministerstwa Skarbu.

W 2008 r., na zlecenie TS z o.o., firma zajmująca się doradztwem inwestycyjnym przygotowała „Koncepcję programowo-przestrzenną zagospodarowania terenów Wyścigów Konnych na Służewcu”. Stołeczny Konserwator Zabytków ocenił ją krytycznie ze względu na zawarty w niej zamiar realizacji obiektów komercyjnych niesłużących sportom konnym. Inna firma doradcza, w ekspertyzie dla TS z o.o. z 2009 r., stwierdzała, iż „celem jest zapewnienie zbywalności nieruchomości", co jest niezgodne z zapisem ustawy o wyścigach konnych. Dokument ten ujawnił parę lat później jeden z radnych Ursynowa. 
W tym okresie mieszkańcy i pracownicy z terenu TS próbowali się organizować, w poczuciu, że należy przeciwdziałać likwidacji osiedla i toru treningowego. Po likwidacji przedsiębiorstwa osoby prywatne ze środowiska wyścigowego przez kolejne piętnaście lat wykonywały prace realizowane wcześniej przez PTWK, które zostały zaniechane przez spółkę, m.in. takie jak opracowywanie statystyk wyścigowych i wydawanie programu dla publiczności. Jedna z mieszkanek Toru została radną dzielnicy i starała się zainteresować wyścigami władze miejskie. Doprowadziła między innymi do wydania przez Narodowy Instytut Dziedzictwa opinii na temat planów inwestycyjnych Totalizatora (negatywnej). Powstało kilka stowarzyszeń. Ich aktywność, podobnie jak działania Parlamentarnego Zespołu do Spraw Wyścigów Konnych, jest jednak znikoma lub żadna w przestrzeniach dyskursu publicznego.

Po zmianie ustawy hazardowej w $2009 \mathrm{r}^{6}{ }^{6}$ internetowe zakłady bukmacherskie mogły organizować tylko te firmy, które uzyskały odpowiednie zezwolenie ministra finansów. Ponadto ustawa zablokowała promocję zakładów wzajemnych. TS z o.o. zaczęło od tego czasu promować koncepcję budowy na terenie TS kasyna, potężnej hali widowiskowo-sportowej wraz z hotelami, centrum biurowym oraz aquaparkiem (rozważano też ulokowanie na TS Stadionu Narodowego). Wedle kolejnych ogłaszanych na łamach prasy planów w miejsce toru treningowego miał powstać park rekreacyjny z boiskami i małym polem golfowym, ponadto restauracje, bary i fitness cluby.

W 2012 r. w Urzędzie Dzielnicy Ursynów powstał MPZP przy ul. Kłobuckiej obejmujący też teren TS. TS z o.o. opracował i złożył do Prezydenta m. st. Warszawy listę wniosków, które, gdyby zostały uwzględnione, umożliwiłyby realizację zarysowanych wyżej planów inwestycyjnych opartych na długoterminowej poddzierżawie terenów. W tym okresie napięcia między PKWK a TS z o.o. w związku $\mathrm{z}$ odmiennymi wizjami funkcji terenów TS zamieniły się w jawny konflikt.

Po wyłożeniu i zgłoszeniu uwag do MPZP grono „wyścigowców” doprowadziło do uruchomienia procedury wysłuchania publicznego. W październiku 2013 r. w Urzędzie Dzielnicy Ursynów podczas spotkania, „wyścigowcy”, w tym prezes PKWK, oprotestowali plany inwestycyjne Totalizatora, które zakładały likwidację miasteczka wyścigowego. Od tego czasu, czyli od października 2013 r., projekt MPZP przy ul. Kłobuckiej nie stanął jeszcze na radzie miasta. Z informacji uzyskanych w 2016 r. wynika, że projekt został uznany na poziomie wojewódzkim za niezgodny z prawem i obecnie jest przeprojektowywany. W 2016 r. prezesem PKWK został były pracownik TS z o.o., co pozwoliło na uzgodnienie stanowisk

6 Ustawa z dnia 19 listopada 2009 r. O grach hazardowych, Dz. U. z 2009 r., poz. 5040. 
obu podmiotów i zredukowanie konfliktu między TS z o.o. i PTWK. Jak dotąd [maj 2017] Totalizator nie wykupił licencji umożliwiającej dostęp do zakładów wzajemnych na Służewcu przez Internet, co stanowi dla wielu „wyścigowców” przyczynek do posądzania TS z o.o. o większe zainteresowanie nieruchomością na Służewcu niż organizacją wyścigów.

Podsumowując, demonopolizacja, wskazywana przez wielu badaczy społecznych i polityków jako jeden z głównych celów transformacji ustrojowej [Kowalik 2009: 144], zakończyła się w przypadku organizacji wyścigów konnych niepowodzeniem. Równocześnie zachowane zostały funkcje tego PGR-u oraz jego podstawowa infrastruktura. Po ćwierć wieku od zainicjowania przekształceń utrwala się złożona instytucjonalnie struktura osobliwa. Komponentami, które uległy prywatyzacji, są własność i trening koni-czyli poziom mikro. Nie doszło jednak do prywatyzacji majątku po PTWK, organizacji wyścigów oraz zakładów wzajemnych. Kolejne próby prywatyzacji były hamowane przez decydentów ze środowiska wyścigowego w obawie przed zmianą funkcji Toru (u progu lat 90. miał powierzchnię 150 ha, a obecnie ok. 139 ha). W kluczowych momentach instytucje państwa (MF, MSP, MRiRW, parlament) uznały, pod wpływem oddolnych działań „wyścigowców”, iż wypracowane dotychczas narzędzia prawne są niewystarczające, aby zagwarantować ochronę instytucji wyścigów na Służewcu w warunkach gospodarki wolnorynkowej.

\section{Idylliczna utopia Państwowych Torów Wyścigów Konnych}

Wraz z wprowadzaniem zasad gospodarki rynkowej, po pierwszych latach euforii i wiary w powszechny awans, wśród „wyścigowców” zaczęły się ujawniać symptomy „zwykłej anomii”, która wynika „,z rozbieżności pomiędzy normami a celami kulturowymi a społecznie ustrukturowanymi możliwościami działania członków grupy zgodnie z tymi normami" [Merton 2002: 266]. Dotyka ona dziś nawet osoby pracujące i wciąż odnoszące sukcesy. Wielokrotny „Trener Roku”, także po 1989, na temat Toru formułuje uwagi w rodzaju:

A teraz się robi pustynia, jeżeli chodzi o Wyścigi, bo to już skansen się zrobił... wszystko umiera... [mężczyzna, trener, mieszkaniec TS, lat 75].

Mieszkańcy miasteczka wyścigowego, którzy tu pracowali i mieszkali przed 1989 r., twierdzą, że ich sytuacja, jak i całej społeczności, uległa pogorszeniu. Przez ponad ćwierć wieku transformacji „wyścigowcy” rozwinęli zróżnicowane strategie adaptacyjne, z których część można dziś interpretować jako opóźniony efekt traumy ustrojowej [Sztompka 2000: 86-95; Gumuła 2008: 276]. Obecne w tym środowisku sposoby mówienia o ostatnim ćwierćwieczu odpowiadaja 
subiektywnym wskaźnikom anomii wyróżnionym (dość oględnie) przez Mertona [Merton 2002: 228-229]. Pomimo że sytuacja Toru od 2008 r. jest względnie stabilna, wśród wyścigowców typowe są opinie, że:

Dawniej było lepiej, nie ulega żadnej wątpliwości... [mężczyzna, lat ok 75, dawniej członek kadry dyrektorskiej PTWK, obecnie komentator wyścigowy],

co wyjaśniane jest często w następujący sposób:

Komuna miała to do siebie, że wszyscy się czuli bezpiecznie [kobieta, lat ok. 60, trener, mieszkanka TS].

We wszystkich rozmowach niezbędnym punktem odniesienia dla opowieści o tym, jak się żyje i pracuje na Torze, jest kontrastowo odmienna przeszłość. W pierwszym rzędzie mieszkańcy Toru wspominają daleko posuniętą samowystarczalność przedsiębiorstwa. Podkreślanie niemal autarkicznego charakteru miasteczka wyścigowego wyróżnia wypowiedzi jego mieszkańców na tle narracji pracowników i mieszkańców innych PGR-ów [por. Szpak 2005]. Z sentymentem wspominają własne gospodarstwo rolne oraz zakres organizacji życia społecznego w przedsiębiorstwie. Z dzisiejszych opowieści wyłania się obraz idyllicznej zamkniętej krainy, w której wszystkie podstawowe potrzeby ludzi były zaspokojone. W kilku wywiadach padało stwierdzenie: ,było wszystko!”, które sugeruje, że to, co jest dziś, mimo że dość dobrze funkcjonuje, to „nic” w porównaniu z okresem dawnej świetności. Dwa przykłady:

Dwieście osób było w tym hotelu, tych chłopaków [stajennych]. I było tak, że jak się przyjmował chłopak do pracy, dostawał mieszkanie w hotelu, przy wypłacie odtrącali mu grosze jakieś tam za całodzienne wyżywienie. Było tak, że: śniadanie przed pracą oczywiście, później, tak koło dziesiątej no była przerwa na drugie śniadanie, każdy przychodził do hotelu, zjadał śniadanie i obiad, i kolacja, i oni się nie martwili o to, że im nie starczy do pierwszego, czy tam do dziesiątego, bo mieli wszystko zapłacone. To było takie miasteczko. Było wszystko! [mężczyzna, lat ok 50, mieszkaniec TS, do niedawna stajenny].

Oraz:

Tak... Absolutnie było wszystko! Był budynek łaźni, który się już zawala, tam była sauna, łaźnia, to w ogóle nie trzeba było wychodzić [do miasta] [kobieta, lat 40, dawniej jeździec amatorka, właścicielka koni].

W dniu likwidacji PWTK na jego terenie funkcjonowały: szkoła dla dorosłych, stołówka, hotel pracowniczy, sezonowe przedszkole, sauna, pralnia, gabinet lekarski i pielęgniarski, szereg klubów sportowych, biblioteka, boiska, korty, ring bokserski, usługi krawieckie, sklep oraz gospodarstwo rolne zajmujące się uprawą kwiatów (do przyozdabiania trybun), trawy dla koni oraz uprawą warzyw i hodowlą kur, kóz, owiec, gęsi, a nawet świń na potrzeby stołówki i mieszkańców. 
Mieszkańcy posiadali też wydzielone z terenu działki pracownicze. Wszystkie wywiady zawierają liczne odniesienia do topografii miasteczka wyścigowego, wciąż niemal monopolistycznie użytkowanego przez wyścigowców.

Mieszkańcy Toru chętnie umawiali się na wywiady na jego terenie i oprowadzali badaczy alejkami i schodkami ,donikąd”. Dawne ogrodowe, pastewne i parkowe części tego rozległego terenu są dziś zdziczałymi nieużytkami. Ślady wyburzeń i pustostany - nieczynne szklarnie, dominujący wizualnie nad miasteczkiem wyścigowym bezużyteczny magazyn zbożowy, pozostałości po gabinecie pielęgniarskim przy torze treningowym czy zardzewiałe szczątki maszyn rolniczych i huśtawek z placów zabaw ukazywały nam fazy podupadania ich świata. Po likwidacji PTWK wygaszane były usługi socjalne oraz organizacje społeczne i kulturalne na Torze. Ich zanikaniu towarzyszyło kurczenie się przestrzeni społecznych, w których mogły istnieć więzy sąsiedzkie, przyjacielskie oraz rodzinne. To one, nie kalendarz instytucjonalnych zmian związanych z transformacją, ukonkretniają przywoływane przez moich rozmówców obrazy przeszłości. Ich nieobecność przynosi fantomowe bóle:

Tu życie tętniło. Był hotel, właśnie idziemy w tym kierunku, gdzie tutaj, no w tym hotelu było wszystko, i biblioteka, i sala muzyczna, i jakieś tam ferie zimowe, można było przyjść, w ping-ponga sobie pograć. [...] A tu było boisko. Mieliśmy swój zespół piłkarski, który nazywał się „Folwark”7. Często graliśmy. Było tutaj dużo zajęć, nie mieliśmy jakichś takich głupich pomysłów, żeby chodzić gdzieś, coś, szyby wybijać, czy coś, tylko albo graliśmy w ping-ponga, albo w piłkę graliśmy... [mężczyzna, lat ok. 45, mieszkaniec TS, sporadycznie pracownik stajenny].

W najstarszych rodzinach „wyścigowych” pamięta się jeszcze postaci „panów" z okresu międzywojennego. We wszystkich wspomnieniach natomiast powraca postać dyrektora PTWK, zwanego też często gospodarzem. Wraz z rozczarowaniem transformacją figura ta uległa na Torze wyraźniej idealizacji [por. Szpak 2005]:

Dyrektor Gniazdowski to był gospodarz, naprawdę! Jego i konie wyścigowe obchodziły i porządek, to wszystko było ładnie! [mężczyzna lat ok. 80, emerytowany koniuszy, mieszkaniec TS].

Nawet paternalistyczny stosunek do pracowników wspominany jest $\mathrm{z}$ humorem, ponieważ uważa się, że wynikał on z troski o wspólne dobro społeczności:

7 W rzeczywistości klub nosił nazwę „Forward”, od imienia konia, który wygrał Derby w 1925 r. Pomyłka jest znamienna - odsyła do skojarzeń związanych ze światem pochodzenia społecznego wielu pracowników Toru Służewiec oraz ilustruje, iż przedwojenna historia wyścigów jest ważna tylko dla nielicznych wykształconych liderów pamięci środowiska mieszkańców PTWK. 
Jak dyrektorem był Gniazdowski, to przede wszystkim był porządek na torach, czyściusieńko wszędzie. To był pedant. On potrafił w nocy jeździć, sprawdzić czy strażnicy pilnują na bramach, czy nie śpią. Prawdziwy gospodarz. Potrafił zadrutować im budkę i zadzwonić przez telefon, że się pali, jak w budzie oni spali. Na drugi dzień poleciał komendant i ich otwarli (śmiech) [mężczyzna lat ok. 70, emerytowany jeździec i koniuszy, mieszkaniec TS].

Tęsknota za gospodarzem, który reguluje życie całej społeczności, przenika nawet do opowieści niektórych właścicieli koni, którzy przecież w tej roli zaistnieli na Torze dopiero po 1993 r. Jedna osoba wręcz negatywnie wypowiada się o społecznych skutkach wprowadzenia rynkowych reguł gry na Tor, choć, w uproszczeniu, zawdzięcza im możliwość posiadania wierzchowców:

Kiedyś to czuło się, że tu byli jakby gospodarze, a teraz to się czuje, że to po prostu jest biznes... [mężczyzna, lat ok. 70, właściciel koni].

Inny właściciel, stosując także figurę gospodarza, podkreśla, że wraz z transformacją ustrojową wpływ mieszkańców na własne sprawy nie zwiększył się, a przeciwnie - zmniejszył, zaś obecni włodarze obiektu traktują pracowników stajni instrumentalnie:

Dzisiejszy gospodarz [czyli TS z o.o. i PKWK], można powiedzieć, tego terenu, stworzył jakąś sztuczną barierę w stosunku do tych ludzi, którzy są za siatką, [dzielącą wzdłuż alei teren na hipodrom i miasteczko wyścigowe]. I zrobiło się tak, jak kiedyś były czworaki, ja to tak określam. Był pan, to był ktoś, kto... Przepraszam, muszę tak rozmawiać... kto by chciał panienkę wziąć, przykładowo, z tamtej drugiej strony i robił z nią, co chciał. I jemu było to wszystko wolno, bo on ma pieniądze [mężczyzna lat ok. 55, mieszkaniec okolic TS, gracz, obecnie właściciel koni].

Spadkobiercami wyidealizowanych obrazów przeszłości, które utrudniają pozytywną ocenę obecnej sytuacji, są młodzi ludzie. Wielu z nich także opowiada o dawnej mapie życia społecznego na Torze: łaźni, sklepie, stołówce, klubach sportowych, podkreślając ponadto za rodzicami negatywny kierunek przemian w obrębie wspólnoty mieszkańców, który jest wynikiem jej opustoszenia:

Jak mama mi opowiadała, w czasach PRL-u jakieś wspólne wycieczki, sprzątanie terenu i wtedy ludzie się... Nie wiem, czy wtedy nimi strach powodował, też były różne czasy, ale jakoś mówi, że tak ona dobrze to wspomina, bo ludzie się spotykali, na przykład sprzątali teren wspólnie i że to było takie fajne i w ogóle, że ta mobilizacja jednak była. Może to bardziej naturalne dla ludzi, to że coś się robi wspólnie [kobieta, lat ok. 25, mieszkanka TS].

Jedność miejsca życia i pracy wpływała na styl życia pracowników PGR-ów. Wymagało to dostosowania się ze strony napływających z zewnątrz pracowników i mieszkańców. W załogach zawiązywały się głębokie więzi rodzinne i przyjacielskie, choć występowały też konflikty [por. Szpak 2005: 93-96]. Pomimo że Tor znajduje się w granicach administracyjnych stolicy, pamięć wspólnoty jego 
mieszkańców trzeba zaliczyć do pamięci chłopskiej - właściwej małym lokalnym wspólnotom, która dotąd przekazywana była tylko w kontaktach bezpośrednich z najbliższymi [Szpak 2005: 190; Głowacka-Grajper 2016: 270].

Od 1993 r. mieszkańcy Toru pracują w kilkudziesięciu rywalizujących ze sobą stajniach, co sprawia, że konfliktów oraz sposobów interpretacji bieżącej rzeczywistości jest więcej. Jednak zasadniczo niezmieniona struktura przestrzenna „miasteczka wyścigowego" sprzyja gęstym sieciom relacji między pracownikami stajni, którzy są też sąsiadami, nieraz powinowatymi. Powoduje to ujednolicenie pamięci komunikacyjnej i sposobów mówienia o przeszłości, jako okresie, w którym wszyscy pracowali dla PTWK i wierzyli, że prywatyzacja przyniesie awans całej społeczności.

\section{Lata dziewięćdziesiąte - czas nadziei}

Pierwsze lata transformacji wspominane są przez znaczną część mieszkańców Toru z sentymentem, ponieważ zręby funkcjonowania PTWK pozostawały niezmienione do końca 1993 r. Jeden z rozmówców, w 1990 r., po likwidacji wiejskiego PGR-u, w którym mieszkała jego rodzina, przeniósł się na Tor za namową pracującego tu już brata:

Tysiąc dziewięćset dziewięćdziesiąty to jeszcze państwowe tory były. Obiady były darmo, wyżywienie całodzienne było darmo. Za konie nadliczbowe, za boksy płacili. Sprzedaż koni, który koń został ze stajni danej sprzedany, płacili. Procent od każdego konia wygranego płacili i za prowadzenie koni do wyścigu też płacili. Także były lepsze czasy jak są... [mężczyzna lat ok. 55, stajenny, mieszkaniec TS].

Obok 2008 r. koniec 1993 r. jest jedyną datą, która pojawia się w kilku wywiadach. Wyznacza granice, po której przekroczeniu rozpoczął się rozpad - choć jeszcze w latach 90. tak tego nie postrzegano:

W 1994 roku po prostu, no w ogóle tutaj takie widmo, że tak powiem likwidacji tego toru nad nami zawisło i jednym ze sposobów na dofinansowanie, żeby państwo chciało w jakiś sposób tu podtrzymać te Wyścigi, to była częściowa prywatyzacja. I dyrektor wymyślił, że najłatwiej będzie sprywatyzować po prostu takimi kawałkami. Czyli, że trenerzy przejmą stajnie. Ci najstarsi, którzy nie chcieli już się, powiedzmy w to bawić, nie [kobieta, lat ok. 60, trener, mieszkanka TS].

W wywiadach powraca figura dyrektora, który „do końca” starał się chronić swoich pracowników przed narzuconymi zmianami. Choć stracili oni całkowicie wpływ na organizację wyścigów konnych, ich sprawstwo zostało, wedle tej narracji, przeniesione przez dyrektora w obszar ekonomiczny. Wymuszony charakter tego procesu jest jednak wyraźny: 
Tak, jak nastapiła prywatyzacja stajni... To był wymóg i to słusznie było, że tak jak było na świecie, że trenerzy na świecie sa firmami, sa podmiotami gospodarczymi, jak u nas to się nazywa. I od tego momentu, już jak ja przychodzę, chcę pracować na Torach Wyścigów Konnych, to już mnie państwo nie zabezpiecza mieszkania. To jest w mojej kompetencji, żebym ja sobie zabezpieczył jakieś lokum [mężczyzna, lat ok. 75, dawniej członek kadry dyrektorskiej PTWK, obecnie komentator wyścigowy].

Na początku lat 90. wierzono, że problemy finansowe przedsiębiorstwa, a następnie sprywatyzowanych stajni, są przejściowe. Można zaryzykować tezę, że społeczność Toru znajdowała się w fazie liminalnej, po której zakładano, że nastapi awans. Czas ten wspominany jest jako okres wielkich nadziei. Wierzono, że na wzór wielu państw Europy Zachodniej, w których wyścigi konne są popularną i dochodową dziedziną rozrywki, na Torze pojawią się „ludzie z pieniędzmi”, którzy ożywią „koński biznes”. Na TS przychodziło więcej jeźdźców amatorów z miasta, do społeczności dołączali też prywatni właściciele koni. Okres „dzikiego kapitalizmu”, kiedy nie działało już PTWK, a podmioty zarządzające Torem zmieniały się jak w kalejdoskopie, był też przedstawiany jako czas wolności. Atmosfera tamtych lat wspominana jest powszechnie jako wyjątkowa, przypominająca wręcz karnawa1:

Teraz już tak nie ma, aż tak dużo takich imprez i takich spotkań po różnych wyścigach. Kiedyś ... to był taki trochę dziki teren [po likwidacji straży zakładowej i przed wprowadzeniem współczesnej ochrony obiektu]. Kiedyś tam rzeczywiście po każdym jakimś wyścigu były takie albo grille przy stajni, albo były na tak zwanej czarnej drodze, tam za torem roboczym. Cała stajnia i cała grupa się jednoczyła. W oczywisty sposób to naprawdę zbliżało ludzi i te więzi takie dosyć mocne były. [...] Z perspektywy patrząc, to trochę taka patologia tam była. Nawet bym powiedziała, że taka dosyć poważna patologia. Ale ja, jako jakby jakiś taki element tej całej układanki, czułam się tam bardzo bezpiecznie. Absolutnie nikt nigdy nikogo do niczego nie zmuszał. I to życie, które było za murem, [czyli w miasteczku wyścigowym] było w ogóle niewspółmiernie bardziej atrakcyjnie i ciekawie w porównaniu do tego, co było w szkole [kobieta, lat ok. 40, dawniej jeździec-amatorka, obecnie właścicielka koni].

Atmosfera fiesty, zarówno wśród mieszkańców Toru, jak i właścicieli koni, jednak przeminęła. Jej wspomnienie kontrastuje z obecną monotonią życia:

Że kiedyś to było tak, że przyszli właściciele... Wygrał koń na przykład czwartą grupę, przyszedł: „Chłopaki no zrobimy jakiegoś grilla, coś”. Wszyscy się ucieszyli, bo to wiadomo, że to jego koń wygrał, wszyscy koło tego chodzą, jest dżokej, który jechał, są jeźdźcy, są obsługujący tego konia. Teraz to jak sam nie wyciągniesz od właściciela i mu czegoś nie powiesz, takiego żebyś skubał... [...] Powiem ci szczerze, że już zbrzydło mnie to. Nie ma tej atmosfery, co była kiedyś, nie ma i chyba już nie będzie [mężczyzna, lat ok. 45, mieszkaniec TS, sporadycznie pracownik stajenny].

Dawne grille przy stajniach są dziś niemal symbolem początków transformacji ustrojowej. Były obfitsze, lepsze, bardziej rodzinne, obchodzone bardziej uroczy- 
ście. Dzisiejsze to tylko nędzna imitacja dawnych ,grilli”. Kapitalizm wytworzył nową hierarchię, która obniżyła status mieszkańców służewieckiej enklawy:

Już nie jest takie z rozmachem jak było kiedyś. [...] Jest tak, że właściciele po wygranym wyścigu to tam, nie wiem, rzuci parę groszy dla stajni na jakieś tam piwo a zapraszają trenera gdzieś do restauracji [mężczyzna, lat ok. 35, pracownik stajenny, mieszkaniec TS].

Skomplikowanych przemian instytucji Toru z lat 1993-2008 nawet ówcześni pracownicy biurowi spółki nie są w stanie dziś po kolei odtworzyć z pamięci. W narracjach pracowników stajni przemiany strukturalne są właściwie nieobecne - skala ich złożoności i przede wszystkim wyłączenie byłych pracowników PGR-u z ich przebiegu powodują że rozmówcy od opowieści o latach nadziei przechodzili po prostu do opisu upadku „wyścigów”. Choć pojawiają się próby opisywania procesów prywatyzacji jako próby normalizacji stosunków ekonomicznych, nikt nie uważa, że zakończyły się one sukcesem. Zanik wielu funkcji miasteczka stanowi tego namacalny dowód:

To jest wszystko wina tej prywatyzacji, zlikwidowania hotelu. Jak by był ten hotel, byłaby inna atmosfera i jeszcze by tu byli pracownicy, by tu byli ludzie. A teraz ktoś dzwoni do mnie... bo przecież chcą wrócić chłopacy z Niemiec, bo już tam też się robi nieładnie w Niemczech. No chcieliby przyjść do tej pracy. No ale gdzie mają mieszkać? No ma wziąć mieszkanie za dwa tysiące, a dwa i pół zarobi na przykład [mężczyzna lat ok. 55, stajenny, mieszkaniec TS].

Analogicznie do wspomnień sprzed 1993 r. niektórzy właściciele koni, niezależnie od swojej pozycji społecznej, podzielają to przekonanie. Również młodzież ,z Wyścig” zgadza się z taką oceną transformacji Toru. Wywiady z mieszkańcami i pracownikami ujawniają powszechne poczucie zagrożenia podszytego fatalizmem, zaś formy wypowiedzi badanych wskazują na powszechne poczucie braku sprawstwa:

Tak w środowisku się mówi, że już będzie coraz gorzej, że te Wyścigi upadają, że to już taka równia pochyła. No, że coraz gorsze nagrody [za wygrane gonitwy], coraz mniej wyścigów, coraz mniej właścicieli dobrych, no i coraz więcej stajni będzie się zamykało. Przetrwają takie duże stajnie, gdzie mają dobrych właścicieli. W końcu pewnie będzie tak, że trening będzie wyprowadzony poza Warszawę, tak jak to Totalizator planował. Bo jak były te takie początkowe plany zagospodarowania terenu. Nie wiem... Toru roboczego nie ma w ogóle [kobieta, lat ok. 25, jeździec].

Poza prywatyzacją na poziomie mikro - trenerów, jeźdźców, pracowników stajennych - w sferze organizacyjnej i własnościowej Tor pozostał w gestii podmiotów państwa. W powyższym układzie instytucjonalnym społeczność sąsiedzko-zawodowa Toru jest właściwie całkowicie pozbawiona wpływu na swoje otoczenie. Mieszkańcy TS od lat żyją na eksterytorialnej wobec władz 
miejskich wyspie, która należy do osoby prawnej Skarbu Państwa PKWK i jest administrowana przez spółkę z.o.o. Skarbu Państwa TS, od której z roku na rok muszą wynajmować mieszkania i stajnie. Wyścigowcy narzekają na standard domów, wskazują na niedostatek latarni, brak koszy na śmieci przy alejkach na osiedlu czy choćby jednego placu zabaw. Mieszkańcy, jako najemnicy, nie mają na to żadnego wpływu (mogą się wyprowadzić, na co jednak większości nie stać). Dodajmy, że nie można tu realizować projektów przestrzennych budżetu partycypacyjnego.

Podsumowując, ustawa o gospodarowaniu nieruchomościami rolnymi Skarbu Państwa z 1991 r. zlikwidowała samorządność pracowniczą i narzuciła PGR-om ścieżkę przekształceń, w której nie zagwarantowano uczestnictwa w zmianach pracownikom PGR-ów i która realizowana była odgórnie przez centralne jednostki administracyjne. Nie stworzono żadnego systemu preferencji dla spółek pracowniczych [Dzun 2005], a „niewidzialna ręka kapitalizmu” nie przyczyniła się do powszechnej poprawy losu mieszkańców Toru. Pomimo że funkcje Toru Służewiec są zasadniczo realizowane, a w stajniach wręcz brakuje rąk do pracy, dominuje negatywna interpretacja przekształceń, które objęły instytucję wyścigów konnych w Polsce. Wspomnienia czasu wielkich nadziei i wiary we własną podmiotowość kontrastują z dzisiejszym fatalizmem, nawet wśród tych, którzy pracują wciąż w wyuczonym zawodzie.

\section{KONKLUZJE}

Analiza pamiętania ostatnich dekad przez „wyścigowców” została osadzona w kontekście makroekonomicznych i instytucjonalnych przemian instytucji wyścigów konnych w Polsce po 1989 r. Uwzględnienie szeroko rozumianego kontekstu gospodarczego i materialnego jej powstawania i reprodukcji pozwoliło ukazać pracę samej pamięci [por. Allen 2004: 140] i jej umocowanie w przestrzeni życiowej badanych. Odniesienie do materialności środowiska, w tym wypadku mieszkańców Toru Służewiec, pozwoliło wyjść poza omówienie symbolicznych filarów tej pamięci i zrozumieć jej wyjaśniające funkcje dla bieżącej sytuacji życiowej i stanu instytucji wyścigów w kraju.

W procesach polskiej transformacji ważny był wymiar ideologiczny, zakładający - jak zauważa Jane Hardy - wszczepienie szeregu idei i przekonań związanych z rynkiem. Analiza biegu zdarzeń na poziomie przekształceń instytucjonalnych pokazuje, że w okresie transformacji neoliberalne idee i dyskursy stały się czymś w rodzaju „mitów uruchamiających”, których zadanie polegało na stworzeniu złudnej jasności sytuacji [Hardy 2010: 87]. Zarzut ten podnosili też polscy badacze, 
m.in. w kontekście prywatyzacji PGR-ów [Dzun 2005: 174-176]. Po likwidacji PTWK mitologia ta stanowiła pożywkę dla wiary „wyścigowców” w możliwość zachowania integralności środowiska oraz dawała nadzieję na różnorakie formy awansu społecznego. W okresie PRL-u PTWK był instytucją osobliwą. Z powodu rywalizacji sportowej i towarzyszącej jej rywalizacji finansowej o nagrody z wygranych i zakładów wzajemnych wiele elementów myśli neoliberalnej było bliskich ich logice życia codziennego przez cały okres PRL-u. Jednak kolejne lata kryzysu instytucjonalnego wyścigów, brak wpływu na kluczowe obszary ich organizacji oraz odczuwanie pogorszenia położenia ekonomicznego mieszkańców Toru zmieniły ich spojrzenie na prywatyzację.

Na poziomie makrostrukturalnym koleje transformacji PTWK są wieloletnią historią zmagań, w których państwo z jednej strony dążyło do tego, aby sprywatyzować instytucję wyścigów konnych, z drugiej strony, na skutek interwencji wąskiego grona osób związanych z wyścigami konnymi w Polsce, starało się utrzymać nad nią kontrolę w celu zablokowania mniej lub bardziej realnego zagrożenia sprywatyzowania Toru jako atrakcyjnego inwestycyjnie terenu. Część decydentów różnych szczebli hamowała procesy prywatyzacji wyścigów, obawiając się nie tylko funkcji ukrytych tego procesu, ale i istnienia niejawnych motywacji jednostek tworzących podmioty ekonomiczne, niezbędne do jej przeprowadzenia. W efekcie ustawa o wyścigach konnych utrwaliła hybrydalną formę wyścigów jako splotu instytucji publicznych i prywatnych, w której główny hipodrom w kraju należy do Skarbu Państwa, a w gestii spółki Skarbu Państwa pozostawiono organizację wyścigów, totalizatora i zarządzanie terenem.

Pomimo zatrudnienia w zawodzie w wielu wywiadach z mieszkańcami Toru pojawia się strategia nazywana „biadoleniem” [Buchowski 1996: 60]. Widmo zmiany funkcji i komercjalizacji przestrzeni pracy i życia oraz nieuchwalenia MPZP wciąż, od blisko ćwierćwiecza, wydaje się tylko odraczane. Na tym tle idealizacja przeszłości z okresu PRL-u okazuje się funkcjonalna, zarówno na płaszczyźnie emocjonalnej, jak i racjonalnej. Rozległa przestrzeń po majątku Towarzystwa Zachęty do Hodowli od blisko osiemdziesięciu lat stanowi dla „ludzi z Wyścig” wspólny mianownik ich życia zawodowego i prywatnego. Powrót, za Mathew Allenem [Allen 2014: 16], do refleksji Maurice'a Halbwachsa o pamięciotwórczej roli przestrzeni pozwala dostrzec, że obecnie opustoszałe przestrzenie po instytucjach społeczno-gospodarczych byłego PGR-u są dla mieszkańców Toru namacalnymi dowodami świetności wyścigów przed $1993 \mathrm{r}$. i równocześnie pozwalają uzasadnić swoje zrytualizowane zakorzenienie w tym środowisku. 


\section{BIBLIOGRAFIA}

AAN/PTWK/3/207 (lokalizacja Archiwum Dokumentacji Osobowej i Płacowej w Milanówku) AAN/PTWK/3/382 (lokalizacja Archiwum Dokumentacji Osobowej i Płacowej w Milanówku) Allen Matthew. 2014. The labour of memory: memorial culture and 7/7. Palgrave Macmillan.

Assman Jan. 2008. Communicative and cultural memory. W: Cultural memory studies. An international and interdisciplinary handbook, E. Astrid, A. Nünning (red.), 109-118. Berlin, New York: Walter de Gruyter.

Baltowski Maciej, Maciej Miszewski. 2007. Transformacja gospodarcza w Polsce. Warszawa: Wydawnictwo Naukowe PWN.

Buchowski Michal. 1996. Klasa i kultura $w$ okresie transformacji. Antropologiczne studium przypadku społeczności lokalnej w Wielkopolsce. Poznań: Drawa.

Blumer Herbert. 2007. Interakcjonizm symboliczny. Perspektywy i metody. Kraków: Nomos.

Bossak-Herbst Barbara. 2015. Zespół Torów Wyścigów Konnych Służewiec w potrzasku reguł gry o przestrzeń. Przestrzeń publiczna i prywatna a przestrzeń społeczna. W: Zmiany w przestrzeni współczesnych miast, M. Malikowski, M. Polak, J. Halik (red.), 125-142. Rzeszów: Uniwersytet Rzeszowski.

Bossak-Herbst Barbara. 2016. Zespół Torów Wyścigów Konnych Służewiec - przedwojenna enklawa. W: Przewodnik socjologiczny po Warszawie, M. Jacyno (red.), 82-99. Warszawa: Oficyna Naukowa.

Dunn Elizabeth. 2017. Prywatyzujac Polskę. O bobofrutach, wielkim biznesie i restrukturyzacji pracy. Warszawa: Wydawnictwo Krytyki Politycznej.

Dzun Włodzimierz. 2005. Państwowe Gospodarstwa Rolne w procesie przemian systemowych w Polsce. Warszawa: Instytut Rozwoju Wsi i Rolnictwa.

Giza-Poleszczuk Anna, Mirosława Marody, Andrzej Rychard. 2000. Strategie i system. Polacy w obliczu zmiany społecznej. Warszawa: Wydawnictwa IFiS PAN.

Golka Marian. 2009. Pamięć społeczna i jej implanty. Warszawa: Scholar.

Gumuła Wiesław. 2008. Teoria osobliwości społecznych. Zaskakująca transformacja w Polsce. Warszawa: Scholar.

Hardy Jane. 2010. Nowy polski kapitalizm. Warszawa: Instytut Wydawniczy Książka i Prasa.

Harper Krista. 2006. Wild capitalism: Environmental activists and post-socialist ecology in Hungary. Boulder, East European Monographs.

Jarosz Maria (red.). 2005. Wygrani i przegrani polskiej transformacji. Warszawa: ISSP PAN Oficyna Naukowa.

Karwacki Arkadiusz. 2006. Błędne koło. Reprodukcja kultury podklasy społecznej (charakterystyka społeczności popegeerowskiej). Toruń: UMK.

Kowalik Tadeusz. 2009. www.Polskatransformacja.pl. Warszawa: Wydawnictwo Literackie MUZA.

Kvale Steinar. 2012. Prowadzenie wywiadów. Warszawa: Wydawnictwo Naukowe PWN.

Mosiej Gerard. 2016. „Kryminologiczne i prawne aspekty zjawiska szarej strefy”. Prokuratura i Prawo (5): 140-167.

Najwyższa Izba Kontroli. 2012. Informacja o wynikach kontroli. Organizacja i funkcjonowanie wyścigów konnych. http://docplayer.pl/5661370-Organizacja-i-funkcjonowanie-wyscigowkonnych.html [dostęp: 1.04.2016].

Nowakowski Krzysztof. 2008. „Wymiary zaufania i problem zaufania negatywnego w Polsce”. Ruch Prawniczy, Ekonomiczny Socjologiczny LXX (1): 213-233.

Rakowski Tomasz. 2009. Łowcy, zbieracze, praktycy niemocy. Etnografia człowieka zdegradowanego. Gdańsk: Słowo obraz/Terytoria. 
Surdykowska Stanisława. 1996. Prywatyzacja. Warszawa: Wydawnictwo Naukowe PWN.

Szpak Ewelina. 2005. Między osiedlem a zagrodą. Życie codzienne mieszkańców PGR-ów. Warszawa: Trio.

Sztompka Piotr. 2000. Trauma wielkiej zmiany. Warszawa: ISP PAN.

Tarkowska Elżbieta. 2013. Dyskursy ubóstwa i wykluczenia społecznego. Warszawa: IFIS PAN.

Tarkowska Elżbieta. 2000. O dawnej i obecnej biedzie w Polsce. W: Zrozumieć biednego o dawnej i obecnej biedzie w Polsce, E. Tarkowska (red.), 49-61. Warszawa: Typografika.

Thompson Paul. 2000. The voice of the past. Oxford: Oxford University Press.

Upchurch Martin, Darko Milinkovic. 2011. "Wild capitalism, privatisation and employment relations in Serbia". Employee Relations 33 (4): 316-333.

Warzywoda-Kruszyńska Wielisława. 1998. „Wielkomiejscy biedni-formująca się ,underclass”? Przypadek klientów opieki społecznej”. Kultura i Społeczeństwo (2): 35-52.

Wnuk-Lipiński Edmund. 2001. Zmiana systemowa. W: Pierwsza dekada niepodległości. Próba socjologicznej syntezy, E. Wnuk-Lipiński, M. Ziółkowski (red.), 37-66. Warszawa: Instytut Studiów Politycznych Polskiej Akademii Nauk.

Barbara Bossak-Herbst

\section{THE COURSE OF INSTITUTIONAL TRANSFORMATION OF THE SŁUŻEWIEC HORSE RACETRACK AND ITS REMEMBRANCE WITHIN THE LOCAL PROFESSIONAL COMMUNITY}

Abstract

This article addresses the issue of the transformation of the State Company Horse Racetrack Służewiec in Warsaw since 1989, and its communicative remembering within the community of the former employee settlements within the Służewiec Racetrack (the current name of the hippodrome).

The first part of the article reconstructs the courses of changes which took place in various levels of decision making and policy with respect to the Służewiec Racetrack and horse racing in Poland. The case analysis shows the process of dialectical initiation and the withdrawal of the state from the de-monopolisation and commercialization of these areas. As a result, it led to the emergence of a hybrid and unmanageable body of private and public institutions that are involved in the organization of horse racing in Warsaw.

An institutional analysis of the transformation of the Służewiec Racetrack serves as a contextual explanation for the second part of the article, in which, on the basis of ethnographic research, the remembrance of these changes within the neighbourhood of the Służewiec Racetrack community is discussed. For the residents, order to describe the present life and work in the stables at Służewiec, it is essential to preserve the narrations about the past. In their remembrance, the changes which took place during last quarter-century are merging into narrations of the racetrack's fall, which has its material correlates in vacancies, ruins and demolition sites in and around the Służewiec Racetrack. It is hypothesized that the unclear and exclusive course of the transformation of the institution of horse racing led to the simplification and idealization of images of the past, which play an explanatory function for the present conditions of the racing community.

Keywords: transformation, social memory, horse racing, Służewiec Racetrack, State Agricultural Farm 